\title{
Chapter 10 SDG 10: Reduced Inequalities - An Environmental Justice Perspective on Implications for Forests and People
}

Bimbika Sijapati Basnett*, Rodd Myers and Marlène Elias

\section{Key Points}

- SDG10 has the potential to reflect a core commitment within the SDGs 'leave no one behind' - and to recognise that the dominant economic system exacerbates inequalities within countries through rules that reinforce the current global distribution of wealth.

- In principle, considerable synergies and complementarities exist between SDG 10 targets and principles of environmental justice (distributive, representative and recognition). However, there is a disjuncture between SDG 10 and SDGs on environmental sustainability, which may undermine efforts to promote environmental justice.

- A key gap in SDG 10 is the failure to include trade in spite of the heightened intensification of markets for forest products driving unsustainable forest resource extraction while exacerbating distributive principles of justice between upstream and downstream actors in global production networks.

- For SDG 10 to properly address inequality structures, it must improve distributive, representative and recognition justice for marginalised populations. This would have a positive impact on forest-dependent populations.

- Addressing migration-related indicators in SDG 10 sheds light on the importance of these issues in forestry policy and research and challenges simplistic assumptions informing existing research. Whether this amounts to significant reduction in environmental injustices would, however, depend on what informs the framing of SDG 10 - concerns for making migration work for development or narrow nationalist fears of looming migrant crisis.

\footnotetext{
* Lead author.
} 


\subsection{Introduction}

As we embark on the great collective journey, we pledge that no one will be left behind. Recognizing that dignity of the human person is fundamental, we wish to see the goals and targets met for all nations and peoples and all segments of society. (UN General Assembly 2015: 1)

SDG 10 calls for reducing inequalities in income as well as those based on age, sex, disability, race, ethnicity, origin, religion or economic or other status within a country. The Goal also addresses inequalities among countries, including those related to representation, migration and development assistance (UN 2018). This is an ambitious goal with many overlapping and distinct targets, as is reflected in Table 10.1. Inequality is understood in this chapter as 'the state of not being equal, especially in status, rights, and opportunities' (UN DESA 2015: 1). The goal recognises the importance of combating economic, social and cultural dimensions of inequalities at the individual, group and societal levels (Kabeer and Santos 2017). Proponents argue that SDG 10 closely reflects one of the core agendas of Agenda 2030 on Sustainable Development - 'leave no one behind' - and shows clear signs of lessons learned from fundamental criticisms levelled against the Millennium Development Goals (MDGs), predecessor to the SDGs (Kabeer 2015, Stuart and Woodroofe 2016, Willis 2016). The MDGs were criticised for focusing narrowly on halving extreme poverty rather than addressing the underlying inequalities that generate poverty in the first place. Hence, SDG 10 is a reaction to growing disparities in income and socio-economic well-being despite overall increases in gross domestic product (GDP), with roots in inclusivegrowth approaches (UNDP 2013).

Likewise, the targets and associated indicators pertaining to inequalities among countries recognise that the dominant economic system exacerbates inequalities within countries through rules that reinforce the current global distribution of wealth (IIED 2016). As demonstrated in Table 10.1, SDG 10 focuses on enhancing representation of developing countries in global markets, managing migration and increasing the flow of funds to poor countries through foreign direct investment and official development flows. In this way, addressing inequalities among countries is both an end in itself as well as a means to reducing inequalities within countries. SDG 10 acknowledges the role that migration and remittances can play in furthering the global development agenda by contributing to the reduction of inequalities at the country and cross-country levels. However, critics point out that SDG 10's emphasis on managing migration reflects growing anxieties over the migrant crisis in Europe, North America and Australia rather than leveraging migration 


\begin{tabular}{|c|c|}
\hline Inequality within countries & Inequalities among countries \\
\hline $\begin{array}{l}\text { 10.1 Progressively achieve and } \\
\text { sustain income growth of } \\
\text { the bottom } 40 \text { per cent } \\
\text { at a higher rate than the } \\
\text { national average }\end{array}$ & $\begin{array}{l}10.5 \text { Improve the regulation and } \\
\text { monitoring of global financial markets } \\
\text { and institutions and strengthen the } \\
\text { implementation of such regulations }\end{array}$ \\
\hline $\begin{array}{l}\text { 10.2 Empower and promote } \\
\text { the social, economic } \\
\text { and political inclusion } \\
\text { of all irrespective of age, } \\
\text { disability, race, ethnicity, } \\
\text { origin, religion or } \\
\text { economic or other status }\end{array}$ & $\begin{array}{l}\text { 10.6 Ensure enhanced representation } \\
\text { and voice for developing countries } \\
\text { in decision-making in global } \\
\text { economic and financial institutions } \\
\text { in order to deliver effective, } \\
\text { credible, accountable and legitimate } \\
\text { institutions }\end{array}$ \\
\hline \multirow{3}{*}{$\begin{array}{l}\text { 10.3 Ensure equal opportunity } \\
\text { and reduce inequalities } \\
\text { of outcome, including by } \\
\text { eliminating discriminatory } \\
\text { laws, policies and practices } \\
\text { and promoting appropriate } \\
\text { legislation, policies and } \\
\text { action in this regard }\end{array}$} & $\begin{array}{l}\text { I0.A Implement the principle of special and } \\
\text { differential treatment for developing } \\
\text { countries, in particular least-developed } \\
\text { countries, in accordance with World } \\
\text { Trade Organization agreements }\end{array}$ \\
\hline & $\begin{array}{l}\text { 10.B Encourage official development } \\
\text { assistance and financial flows, } \\
\text { including foreign direct investment, } \\
\text { to states where there is greatest } \\
\text { need, in particular least-developed } \\
\text { countries, African countries, small } \\
\text { island developing countries, and } \\
\text { landlocked developing countries }\end{array}$ \\
\hline & $\begin{array}{l}\text { 10.7 Facilitate orderly, safe, regular and } \\
\text { responsible migration and mobility } \\
\text { of people, including through } \\
\text { implementation of planned and well- } \\
\text { managed migration policies }\end{array}$ \\
\hline $\begin{array}{l}\text { 10.4 Adopt policies, especially } \\
\text { fiscal, wage and social } \\
\text { protection policies, and } \\
\text { progressively achieve } \\
\text { greater equality }\end{array}$ & $\begin{array}{l}\text { 10.C Reduce to less than } 3 \text { per cent } \\
\text { the transaction costs of migrant } \\
\text { remittances and eliminate remittance } \\
\text { corridors with costs higher than } 5 \text { per } \\
\text { cent }\end{array}$ \\
\hline
\end{tabular}


and development for socially just, environmentally responsive development (Nijenhuis and Leung 2017).

This chapter evaluates the potential effects of addressing SDG 10 on forest outcomes using an 'environmental justice lens' (Forsyth 2014, Forsyth and Sikor 2013, Fraser 1995, 2009; Martin 2017, Sikor and Newell 2014). We focus on three principles of environmental justice, which relate to 'distribution', 'representation' and 'recognition'. This perspective shows considerable synergies and complementarities between SDG 10 and environmental justice goals; it also exposes pitfalls, contradictions and trade-offs.

First, we show that because SDG 10 narrowly translates its aspirational goals into easily measurable indicators, addressing SDG 10 may risk undermining representative, distributive and recognition notions of justice. Second, the disjuncture between SDG 10 and the other SDGs may mean that resource distribution, recognition and representation could be sidelined. Third, a key gap in SDG 10 is the absence of trade despite an intensification of markets for forest products driving forest resource extraction while exacerbating distributive justice between upstream and downstream actors in production networks (Myers and Muhajir 2015, Myers et al. 2017, Myers et al. forthcoming).

We combine an overall evaluation of SDG 10 with a more detailed focus on two clusters of targets and indicators related to inequalities within countries (SDG Targets 10.1-10.4) and migration and remittances (10.7 and 10C), and we draw on existing literature on these topics in forestry. The scholarship concerned with inequalities in forestry has long recognised that there is no direct causal relationship between inequalities and forest outcomes (Agrawal and Benson 2011, Agrawal and Gibson 1999, Agrawal and Ostrom 2001, Johnson 2004, Poteete and Ostrom 2004). Institutions, or formal and informal rules and norms that govern how forests are managed, mediate the effects of inequalities on forests and people. We will show that this literature remains divided between those concerned with inequalities to the extent that they influence environmental outcomes and those who view preexisting social relations as fundamentally constituting institutions. The latter suggests that for institutions to properly promote environmental justice requires addressing the socio-economic, cultural and symbolic inequalities (re)produced in institutions. From this perspective, if SDG 10 successfully reduces broad-based inequalities, as outlined in Targets 10.1-10.4, this will in turn reduce environmental injustices on marginalised individuals and groups in forests. But this hinges on whether, to what extent and how SDG 10 will amount to such substantive reductions in inequalities.

We will point out that addressing the migration-related targets and indicators in SDG 10 may contribute to elevating the importance of focusing on 
these issues in the forestry literature too. Most forestry research either ignores the role that migration, mobility and remittances play in current forest transitions or makes far-fetched conclusions about its effects on forests (Hecht et al. 2015). However, it is unclear whether SDG 10, in the way it is framed, opens room for promoting environmental justice for poor and marginalised groups through well-managed migration and remittances.

In what follows, we outline the conceptual framework that informs our analyses (Section 10.2). We then provide an overall evaluation of the gaps and openings in SDG 10 and dive deeper into two clusters of issues - inequalities within countries (Section 10.3) and migration and remittances (Section 10.4). Section 10.5 offers a summary and concluding remarks about potential trade-offs, shortcomings and new openings.

\subsection{Principles of Environmental Justice: An Approach to Evaluating SDG 10}

Environmental outcomes include forest productivity, availability of natural resources, biological diversity and carbon sequestration (World Bank 2009). Human well-being encompasses economic, social and political dimensions. We focus on the human well-being outcomes related to inequality, which encompass economic, social and political dimensions. An environmental justice perspective is particularly well-suited as it acknowledges the inherent synergies, tensions and trade-offs of equality and environmental goals and the need to find a balance between the two, rather than assume win-win outcomes.

Justice is broadly defined as fairness (Rawls 1999), yet what fairness means is contested (Sen 2009). Environmental justice, as a theory and a practice, has a long, rich history in the Global North, particularly in the USA (Agyeman 2005, Bullard 2005, Cole and Foster 2001). More recently, social movements, international organisations and businesses in the Global South widely use the language of justice to lend credibility to their struggles. Examples include local communities and environmental activists resisting dispossession from customary land, opposing polluting industries and struggling for fair distribution of natural-resource revenues. These also include international donors and governments seeking to promote a rights-based approach, and/or rectify past injustices (Newell 2006, Sikor 2010, Sikor and Stahl 2011, Walker 2009).

Different actors bring different notions of (in)justice in environmental struggles depending on the historical circumstances they inherit and the contemporary political economy they must navigate (Forsyth 2014, Forsyth and 
Sikor 2013, Martin 2013). Certain assertions about justice find public support; others are rejected outright as illegitimate concerns (Kumar 2014, Mulvaney 2014, Sikor and Newell 2014). There is often a gulf between justice principles and implementation efforts, with national and local political and economic factors often subverting original intentions (Mehta et al. 2014). The challenge, as Sikor and Newell point out (2014: 153), is to ask 'what kinds of justice are being asserted, by whom and for whom'.

Notwithstanding the plurality of conceptions and practices of justice, as Schlosberg (2004, 2007) points out, everyday struggles and mobilisations around justice are about distribution of environmental goods and bads, recognition of particular group identities and histories, and participation in decision-making. Within this, three notions of justice are apparent: distribution, recognition and representation. These principles build on Fraser's (1995, 2009) understanding of justice.

Distribution notions of justice emerge from socio-economic injustice in the form of exploitation (having the fruits of one's labour appropriated by others); economic marginalisation (being confined to poorly paid work or dearth of income-generating opportunities); and/or deprivation (being denied basic living conditions). The remedies to distributive injustices call for political-economic restructuring, which might involve redistributing income, altering division of labour and/or transforming other economic structures.

Recognition justice aims to remedy symbolic-cultural injustices: revaluing identities against cultural domination, valorising socio-cultural diversity against non-recognition or transforming society against disrespect. Such injustices take many forms, but some are ascribed from birth and hence harder to shed (Fraser 1995, 2009). The remedies may involve cultural and symbolic change such as upwardly revaluing certain identities, recognising and publicly valorising socio-cultural diversity, and/or wholesale transformation of societal representation in ways that would change everyone's sense of self.

Representation justice is about parity of participation in processes: society is fair to the extent that it makes participation possible for all members in institutionalised values and norms, in deliberation processes about distribution rules and in social interactions. These parity principles apply to all spheres of life: from family, market, and informal and formal politics to various civil society associations (Fraser 2009).

All three justice notions are intertwined. Cultural norms biased against marginalised social groups are underpinned by material support from the state or market. For instance, the caste system in Nepal, introduced in the 
eighteenth century by the ruling elite, resulted in the subjugation of a diverse population, with systematic political favours to some and marginalisation to others (Guneratne 2002, Hoffer 1979, Levine 1987). Meanwhile, economic disadvantage impedes parity of participation in cultural and social life. Continuing with the example from Nepal, a major reason why low-caste members and minorities are under-represented in natural-resource management derives from high opportunity costs to participating meaningfully in such processes (Agarwal 2016, Bennett et al. 2013). While the three justice notions reinforce one another, some distinctions are important as one notion is not a precondition for another. Accepting some notions of justice by powerful actors can mean jeopardising others. For instance, Myers and Mujhair's (2015) research in Indonesia found that while Indigenous peoples living in or adjacent to the national park decry the lack of material benefit from the park, they have resisted the state's offers for material benefits on the grounds that consenting to such offers would constitute acceptance of state authority over their customary land and its continued non-recognition of their rights. A justice understanding of inequality highlights the importance of how (in) equalities are framed and by whom.

We use these three notions of environmental justice to evaluate the effects of SDG 10 on marginalised individuals and social groups in forests. We provide an overall evaluation of SDG 10 and then focus in-depth on two clusters of targets and indicators dealing with inequalities and migration.

\subsection{An Overview of Complementarities and Gaps between SDG 10 and Environmental Justice}

SDG 10 Targets 10.1-4 are articulated in ways that recognise how a wide range of economic, social and political variables are distributed among individuals, between social groups, and across multiple and intersecting groups (Kabeer and Santos 2017). Target 10.1 recognises income disparities within a country and Target 10.3 recognises opportunity distribution; both share considerable complementarities with distributive notions of justice. Target 10.2 calls for empowering and promoting the social, economic and political inclusion of all (irrespective of age, disability, race, ethnicity, origin, region or economic or other social status), which is compatible with recognition and representation notions of justice. Target 10.4 acknowledges policies to address diverse social, economic and political inequalities in line with all three notions of environmental justice.

Despite this, there is a disjunction between the way SDG 10 targets are articulated and the indicators selected for measuring target progress. While 
Target 10.2 aims for social, economic and political inclusion for all 'irrespective of age, sex, disability, race, ethnicity, origin, religion or economic or other status', Indicator 10.2.1 measures progress in economic terms only and in regards to 'age, sex and persons of disabilities'. The indicator is arguably easier to measure because countries likely collect statistics on income, which in turn can be disaggregated by age, gender and perhaps by disability. Social and political inclusion of all is difficult to translate into a measurable indicator. Many countries do not collect adequate data on race, ethnicity and/or religion, especially if these relations are highly politicised and/or a narrow subset is officially recognised (Sijapati Basnett 2018, UN Women 2018).

The extent to which representative and recognition notions of justice can be addressed through SDG 10 will be restricted if countries are only held accountable for progress against the very narrow Indicator 10.2.1. An environmental justice perspective would prompt attention to a broader array of potential reforms related to recognition of who the marginalised are and what sustains their marginalisation; distribution of broader social, economic and political resources beyond income; and parity of participation of marginalised social groups in decision-making.

SDG 10 is disconnected from SDGs pertaining to environmental sustainability (such as SDGs 12-15). The potential tensions, trade-offs and synergies between SDG 10 and these environmental SDGs remains unacknowledged. Such a disjuncture is problematic because environmental justice scholarship is increasingly concerned with the effects environmental solutions spurred by global environmental challenges have on localised struggles (Sikor and Newell 2014). For instance, SDG 15 (Life on Land) - the SDG that deals directly with forests - only alludes to distributive justice once, in Target 15.6, and specifically in the context of access and utilisation of genetic resources. Meanwhile, Target 15.A calls to 'mobilise and significantly increase financial resources from all sources to conserve and sustainably use biodiversity and ecosystems'. In this regard, the environmental justice and political ecology literature (Li 2017, Peluso and Lund 2011, Ribot and Peluso 2003, Schoenberger et al. 2017, White et al. 2012) points to the very unequal distributions of access to, and control over, natural resources that such pursuits generate, and the ways in which they create and exacerbate place-based conflicts related to cultural recognition and political self-determination (Newell 2005, 2007). The ensuing conflicts are then as much about whose notions of justice and framings of environmental problems are privileged as about competition over access to and control over material resources (Fraser 2009, Jasanoff and Martello 2004, Sikor 2013). 


\subsection{1 'Trade' as a Major Lacunae in SDG 10}

Trade is not explicitly mentioned in SDG 10. It is arguably a precursor to SDG 8 (Decent Work and Economic Growth) which only explicitly mentions increasing aid for trade (Target 8.A). SDG 17 (Partnerships for the Goals) includes a set of targets related to trade but only mentions strengthening the World Trade Organization (WTO) trading system (Target 17.10), improving the market share of developing countries (Target 17.11) and reducing trade barriers (Target 17.12). Forest resource extraction is largely about markets and trade. Trade has also been a major driver of inequality among countries since colonial times when the dominance of colonial powers was imposed over resource-rich (natural and human) (Hickel 2017). SDG 10 has a lacuna: the neoliberal global trading system produces inequalities both among and within countries (Hickel 2017). While this was certainly an argument that Marx (1867) made, contemporary scholars continue to make the point of the incompatibility between the global system of trade and equality (see Harvey 2004, Moore 2010, Thurow 1975, Williamson 2000).

Trade of forest products includes timber, non-timber plant species, animal products and carbon (which reinforces the place of conservation in markets). Heightened intensification of markets for forests and forest products in the contemporary era means that a wider range and combination of actors are now involved in regulating global forest trading regimes, each with their own implications for others (Maryudi et al. 2015, Maryudi and Myers 2018, Myers 2015). These include different layers of the state, various private sector interests, global NGOs and organised and spontaneous civil mobilisations. Such processes add pressure on some actors and bestow more control on others. Hence, the globalisation of these markets is fertile ground for understanding inequalities and resulting environmental injustices at global and local levels (Bair 2005).

Global markets also affect access to non-timber forest products, and thereby forest-dependent livelihoods (Belcher and Schreckenberg 2007). Studies show a direct correlation between the value of a product and the extent to which powerful actors exercise control over harvesting, production and trading (Dove 1994, Wollenberg 2001). Markets are a significant driver for local peoples to engage with forests (Ruiz-Pérez et al. 2004). As global market prices increase, so does the involvement of powerful, connected and risk-tolerant actors, which then pushes out less-powerful actors. Examples include gaharu (swiftlet nests) in Southeast Asia (Marcone 2005, Soehartono and Newton 2002), and shea in West Africa (Elias and Arora-Jonsson 2017, Elias and Carney 2007). These processes create and exacerbate distributive injustices especially, and, as we show shortly, can also have consequences for representative and recognition justices. 
Anti-deforestation strategies of the 1970s-1990s relied mainly on state- or bilaterally enforced log-export bans and protection of vulnerable species. Now, supranational policies and actions address illegal logging by cutting off the markets for illegally harvested timber. The 2003 EU Forest Law Enforcement, Governance and Trade (FLEGT) Action Plan outlines a system in which (almost) all wood and timber products entering the EU must be proven legal. Efforts to reduce import of illegal timber have also resulted in laws in the USA (US Lacey Act 2008 amendment), Australia (Australian Illegal Logging Prohibition Act 2012) and Japan (Japanese Clean Wood Act 2017). These initiatives are based on a notion of legality that is often rooted in hegemonic notions of forests as a global good - frequently at odds with the interests of local communities (Myers et al. forthcoming).

The EU FLEGT Action Plan and the EU Timber Regulations dictate that traders must demonstrate timber legality through document trails and verification systems. This can have significant implications for small-scale producers (Cerutti and Tacconi 2008, Hajjar 2014, Maryudi and Myers 2018). Maryudi and Myers (2018) show that the increased administration and costs of verifying legality in Indonesia have exacerbated the concentration of power among the bigger and wealthier manufacturers and exporters. Distributive injustices arise when processing is increasingly focused around larger actors, based on the island of Java, with smaller actors, especially on peripheral islands, unable to comply with or make arrangements to otherwise adapt to increasing requirements.

Private certification of sustainable forest products by groups such as the Forest Stewardship Council (FSC) and Programme for the Endorsement of Forest Certification (PEFC) serves as yet another emerging form of forest governance that bypasses the state to implement a non-state solution to the problem of unsustainable forestry practices (Schepers 2009). The FSC, for instance, was a response to the lack of progress after Rio in 1992. The World Wide Fund for Nature (WWF) and a coalition of environmental and social NGOs formed the FSC (Bartley 2007, Cashore et al. 2007, Espach and Ralph 2006). Like FLEGT, FSC represents a relatively new way of governing forests by cutting across local, national and international levels in novel ways to connect the Global North and South. While such private certification enables more direct linkages among actors, it is only available to those who can afford it and who have the required knowledge to navigate the complicated process to comply with standards. In this way, private certification reinforces or creates new forms of distributive injustices.

While the state's role in creating and exacerbating injustices has been well documented (Byrne et al. 2016, Lund 2016, Peluso 1994, Scott 1999), the unprecedented influence of non-state actors is also problematic because 
concerns of rights and equality are on the periphery of the current policy focus. Furthermore, these recent developments disrupt normative systems of accountability between the state and its citizens without offering alternatives to advance democratic citizenship and parity of participation for marginalised forest-dependent peoples.

The inequalities embedded in globalised trade regimes have led to counterclaims of social and environmental injustices - human rights violations, ecological integrity threats and future capabilities harm (Forsyth and Sikor 2013, Martin 2017, Schlosberg 2013, Sikor 2013, Sikor and Stahl 2011, Walker 2012). These claims of injustice provide the impetus for initiatives to facilitate collective action beyond the nation state (Bernstein and Cashore 2007), such as the SDGs, a number of which touch on forest issues. In response, new markets have emerged for forest resources that aim to pay local communities for the provision of ecosystem services - protecting forests to store carbon e.g. Reducing Emissions from Forest Degradation and Deforestation (REDD+). Such conservation efforts use distributive notions of justice to compensate local communities for the opportunity costs or the loss of access to customary forestland from which they derive food, medicines and materials.

However, critics point out that such compensatory mechanisms (financial payments and livelihoods training) insufficiently recognise customary rights and community identities tied to forestlands. Furthermore, engaging local and Indigenous peoples to participate in predetermined notions of sustainable forest management is insufficient to satisfy representation claims of injustice when local perspectives have no place in decision-making or defining forest outcomes (Schroeder et al. 2014). While the claims of recognition injustices are far from new, the legitimisation of these claims is historically unprecedented. These calls challenge the dominant conceptions of justice enshrined in tropical forest governance and call into question whose version of forest governance, shaped by trade, is adopted at global and local levels. They push the boundaries of what equality means for different actors. The question then is whether SDG 10's principles of equality, as outlined in the targets and corresponding indicators, are sufficient.

\subsection{Inequalities within Countries and Forests - Targets 10.1-10.4}

Unlike many topics covered in SDG 10 that have received less attention in forestry/environment scholarship (such as migration and remittances, global financial markets, global institutions), the relationship between inequality within countries (Targets 10.1 and 10.4) and environmental outcomes have long been a matter of debate (Martin 2017). Environmental degradation, 
including forest loss and degradation, can reinforce socio-economic and cultural inequalities, and inequalities influence environmental and forest management (Islam 2015). In what follows, we draw from two schools of thought - 'commons' and 'entitlement' scholarship (Johnson 2004) - concerned with this relationship. They differ with regard to their normative commitments, interpretation of institutions and conceptual and methodological approaches. We will demonstrate that the 'entitlement' school of thought offers more insights on whether and under what conditions reducing inequalities, as outlined in SDG 10, contributes to environmental justice.

A first school of thought, which Johnson (2004) refers to as 'commons scholars', is concerned with the influence of inequality on the efficiency and environmental health of the commons. It largely consists of modelling individual behaviour based on rational choice theories to explore how institutions can keep users from overexploiting or degrading the commons. Within this literature, authors offer different views of the relationship between socio-economic inequality or heterogeneity, collective action or local governance institutions, and environmental outcomes. Their research is largely informed by theory and case studies, and, in many of the works cited, positive ecological outcomes from collective action and/or well-functioning forest-governance institutions are assumed rather than empirically demonstrated (Andersson and Agrawal 2011).

Within 'commons' scholarship, a large body of research demonstrates a positive relationship between socio-economic equality, largely assessed on the basis of wealth holdings and forest condition (Budhathoki 2004, Trawick 2001). Its authors argue that socio-economic inequality leads to exclusionary decision-making (representative injustice) (Neupane 2003), distrust (Seabright 1993) and an unequal distribution of benefits from commonly managed resources (distributive injustice) (Moore 1993). Lack of social cohesion and disincentives for the rich - who can benefit from private resources - to contribute to collective action can hinder collective action and lead to inefficient resource governance (Chatterton and Chatterton 2001, Corbera et al. 2007, Mukhopadhyay 2004, Smith 2004), perverse resource-use strategies and less ecologically sustainable governance outcomes. One of the few multi-locality, cross-country comparative studies of forest-user groups $(n=228)$ empirically demonstrates that economic inequalities within and across these groups consistently lead to negative forest outcomes (Andersson and Agarwal 2011). ${ }^{1}$

\footnotetext{
${ }^{1}$ The study draws from data from the International Forestry Resources and Institutions (IFRI) network. The IFRI network (http://ifri.forgov.org/) brings together 14 Collaborating Research Centers (CRCs) worldwide that examine how governance arrangements affect forests and forest-dependent peoples. Using a common methodology, these CRCs have collected data on biodiversity, livelihoods, institutions and forest carbon for more than 250 sites in 15 countries since 1992.
} 
Other commons scholars posit the contrary: that socio-economic inequality (linked to notions of distributive justice) can be positively related to environmental outcomes. This literature builds on Olson's (1965) influential work on privileged groups, which sees group heterogeneity as supporting collective action assuming that rich individuals bring benefits to the rest of the group (Sandler 2015). As the argument goes, there can be high costs to initiating and maintaining collective action, which may more readily be borne by better-resourced individuals than in a decentralised manner among a homogenous group (Hardin 1982). Wealthier individuals may bear these costs either for the sake of a well-functioning institution or for a greater share of benefits from common pool resources (Baland and Platteau 1999). In this view, complementarities amid socio-economically differentiated groups can promote cooperative resource management (Quiggin 1982), and social exclusions can encourage collective action among the disenfranchised (Jodha 1985), leading to more favourable resource management outcomes.

Finally, some commons scholars demonstrate a non-linear, U-shaped relationship between equality, local governance and ecological outcomes (Baker 1998, Dayton-Johnson and Bardhan 2002, Molinas 1998, Zapata et al. 2014). In a comparative study of 104 local peasant cooperative institutions in Paraguay, Molinas (1998) identifies lower levels of cooperation among both the least and the most unequal (based on endowments) organisations. In the low inequality cases, the capacity to bear the costs of collective action was low, whereas resentment and out-migration occurred in highly unequal contexts and impeded cooperation. Similarly, Baker (1998) notes that some inequality can allow certain individuals to carry a bigger share of the organising costs of collective action, but too much inequality can diminish shared interests in the collective good. Zapata et al. (2014) underscore that any such analysis must consider how power is distributed within communities, as well as the interests of the more powerful actors. Using panel data from the Bolivian Amazon, they find a negative correlation between income inequality at the village level and deforestation at the household level, which they claim supports the idea that 'unilateral conservation' can occur when wealthier actors perceive more benefits than costs from environmental conservation, and vice versa.

In one of the few studies explicitly and empirically examining the threeway relationship between heterogeneity, collective action and forest outcomes, Varughese and Ostrom (2001) find that spatial, caste and ethnic, and wealth inequalities - linked to recognition and distributive notions of justice, respectively - among forest-user-group members in Nepal pose challenges but do not in themselves determine the success of collective action. When groups have autonomy to make their own rules, they can overcome stressful 
heterogeneities through institutional arrangements adapted to their local circumstances. In Nepal, Adhikari and Lovett (2006) echo that the effects of heterogeneity on collective action can vary widely and recommend flexible systems of governance that can allow management regimes to be adapted to local conditions. Poteete and Ostrom (2004), in turn, based on a multicountry review of IFRI studies, note that heterogeneity and the size of user groups affect collective action in contextually specific ways. The authors argue that the importance of group characteristics may depend on other attributes of the resource and resource users, and that interaction effects and contingent relations play a role in explaining divergent findings. Inequality thus interacts with forest market conditions, management rights and rules, for example, to shape forest outcomes.

Influenced by the literature on entitlements (Sen 1981, Leach et al. 1999), 'entitlements scholars' (Johnson 2004) bring a different focus to these analyses. They elucidate that positive forest outcomes will rarely equally benefit all users, including poor and marginalised social groups that rely most on the forest and have the least voice and influence in decision-making processes. Hence, while recognising that environmental outcomes are critical, they argue for local institutions that enable poor and marginalised groups to access and use the commons to their benefit, thereby furthering distributive, representative and recognition notions of justice in their own right (Agarwal 2001, 2002, 2010, Bandiaky 2008, Cleaver 2002, Moore 1993, Peluso 1994, Sikor and Lund 2010).

Taking a historical perspective, entitlement scholars focus on the structures operating across scales (micro to macro) that shape social relations and reinforce (in)equalities in the commons. They underscore the complex, uncertain and dynamic processes and relations underpinning access to and control over resources, environmental management and social and ecological change (Scoones 1999). In this perspective, policies and multi-scalar socio-political processes, as well as historical and path-dependent patterns of resource use, non-place-based relations (e.g. markets) and the presence and power of different state and non-state actors and authorities, contribute to shaping forest outcomes (Coomes et al. 2016, Mearns 1996, Rangan and Kull 2009, Robbins 2004, Zimmerer and Bassett 2003).

This scholarship begins with the recognition that power relations, and thus inequalities, are embedded in formal or bureaucratic institutions (introduced through organisations and legal structures) as well as informal or socially embedded institutions (based on culture, social organisation and everyday practices) that govern common property resources (Cleaver 2002). Because institutional processes of formation, maintenance and change are inherently power laden and asymmetrical, institutional arrangements do not affect nor 
are they affected by inequalities; rather, they are constituted by them, as inequalities are at the very heart of institutional building and change (Agrawal and Gibson 1999). Ideologically embedded inequalities linked to gender and/ or ethnicity or caste (recognition notions of justice), as well as those linked to political participation (representative justice) and access to and distribution of resources (distributive justice), are thus reproduced and reinforced in forest-governance institutions (Agarwal 2002, 2010, Cleaver 2002). These constituent inequalities problematise assumptions that local institutions are rooted in moral economies based on equity, social welfare and security (Li 1996, Mosse 1997).

Studies across regional contexts show that collective resource management institutions and initiatives often reinforce representative injustices, excluding poorer households and groups marginalised on the basis of gender, caste or landlessness (recognition justice), thereby reinforcing existing power disparities and hierarchies (Agarwal 2001, 2010, Astuti and McGregor 2016, Beck and Nesmith 2001, Hébert and Rosen 2007, Taylor 2000). Even when such groups are formally represented in committees of forest-user groups, skewed power relations and their lack of recognition in these spaces typically result in limited participation and influence over decision-making processes and related outcomes (Agarwal 2001). For example, Sunam and McCarthy's (2010) work on community-forest-user groups in Nepal shows that procedures for electing committee members favour better off, male, upper caste residents, and the interests of powerful elites rather than marginalised forestdependent groups. Still in Nepal, Chaudhary et al. (2018) demonstrate that such exclusions in participation and representation result in an inequitable distribution of benefits from the forest.

Likewise, in Tanzania the framing of the community-based forest-management policy in technical and procedural terms reproduced intra-village inequalities, as it called for local expertise and required literacy and administrative skills to respond to the system's bureaucratic obligations. As only wealthy and powerful villagers were considered 'experts', this village elite dominated local decision-making processes and conservation narratives as well as distributive benefits from forest-related income (Green and Lund 2014; see also Khatun et al. 2015 on elite control in REDD+ Tanzania, and Kopnina 2017 on elite capture of commodified natural resources and forest ecosystem services). In other contexts, women and less-powerful men have been systematically excluded from collective management institutions (Mosse 1997, Taylor 2000), or have participated only nominally, without real voice or influence (Baynes et al. 2015).

Of concern from an environmental justice perspective is not only how inequality affects access to and influence in governance processes (representative 
justice), but also whether or how processes of institutional formation and change create and sustain resource access for vulnerable groups (distributive justice). For instance, Agarwal $(2001,2010)$ points out that in India and Nepal, rules of entry in forest-user committees, participation in decisionmaking and principles of distribution of resources reproduce inequalities on the basis of gender and caste in seemingly participatory community-forestry user groups. In Kenya, the distribution of REDD+ benefits accrued first and disproportionately to larger landowners, with patterns of land ownership reflecting land dispossession processes rooted in colonial times (Chomba et al. 2015). A review of the social impacts of neoliberal conservation underscores that the 'commodification and marketisation of nature creates new rents and incomes for formal or informal appropriation by elites and patronclient networks' (Holmes and Cavanaugh 2016: 205). Li (2018, personal communication) argues that the current forest-tenure reform championed in Indonesia (Siscawati 2017) only favours social groups that can conform to state-sanctioned definitions of indigeneity (recognition justice), which may not easily correspond to complex social realities, thereby creating new forms of contestations and exclusions. Similarly, a comparative assessment of forest-tenure reforms in 30 countries across Asia and Africa shows that new statutory rights do not automatically translate into rights in practice, and that institutional weaknesses and policy distortions thwart environmental justice (Larson et al. 2010). Additionally, the justice that is to be translated through international and national programmes such as REDD+ is typically framed in global narratives that focus on participation (representative justice) or material concerns (e.g. benefit-sharing from REDD+) (distributive justice), overlooking local understandings of justice and the experiences of dispossession of identity (recognition justice) tied to nature and land (Suiseeya 2017).

\subsection{Migration and Remittances - Targets 10.7, 10.C and 17.3}

Many observers hail the SDGs for explicitly recognising migration for the first time in the global development agenda. By devoting two indicators to migration and remittance out of a total of nine indicators in SDG 10, it is clear that migration and remittance are being framed in the SDGs as a way of addressing inequalities within and between countries. Target 17.3 further views remittances as 'mobilising additional financing resources for developing countries from multiple sources'. The SDG framework, therefore, recognises that migration and remittances potentially contribute to the GDP of poor countries and help reduce income inequalities within and between countries (Appave and Sinha 2017).Target 10.7 emphasises 'planned and well-managed migration 
policies' (orderly, safe, regulated and responsible migration and mobility), even as the corresponding Indicator (10.7.1) only mentions number of countries that have implemented well-managed migration policies but does not define what this means.

Forestry policies and academic scholarship have been slow to catch up despite the prominence of migration in the global development agenda and the fact that enhanced mobility and the remittances generated by mobility are key elements of current transitions in forested landscapes of developed countries. As Hecht et al. (2015) found through a review of existing literature, much forest-based research assumes that rural households and communities are largely static and spatially bounded, while issues of migration, mobility and remittances lie outside the attention of most natural-resource-governance policymakers. Where forestry and environmental policy do acknowledge migration, it is often seen as disruptive or a sign of livelihood failure. The scholarship that does exist remains premised on simplistic and dichotomous assumptions that view in-migration into forested areas as a cause of tropical deforestation and out-migration as leading to forest regeneration and growth (Carr 2009a, 2009b, Hecht et al. 2012, 2014, Wunder et al. 2014a, 2014 b). Each of these potential impacts of migration on forests is possible, but there has been limited research on the many mediating factors that influence these outcomes. These may include a wide variety of social, economic, political and environmental factors playing a role in determining outcomes for forests and peoples, including from an environmental justice perspective. These include time and type of incorporation, feedback loops of economic development and technological change, changing tenure systems, differences in cultural norms and different forms of migration. Instead of these simplistic views, Black et al. (2011) rightly point to the importance of examining the multiple drivers and net effects of migration/environmental change.

The literature on forests and migration in Indonesia is a case in point. Based on an extensive review of literature, Thung and Juniwaty (2018) find that in the 1980s and 1990s, deforestation and forest degradation were often blamed on environmentally destructive migrants, with Secrett's 1986 article in The Ecologist often credited with initiating such a discursive trend. Since the decline of the state-sponsored transmigration programme, through which poor Javanese were resettled in the forest frontiers of Indonesia's remoter islands, attention has mostly shifted towards spontaneous migration (see, for instance, Potter 2012), with many researchers drawing conclusions similar to previous studies and perpetuating negative images about migrants. A number of scholars have also sought to quantify the effects of in-migration on forest cover change through various GIS and statistical analyses. For instance, coupling satellite imagery on forest cover change between 2000 and 2007 with 
results of the housing and population censuses of 2000 and 2010, Darmawan et al. (2016) found a strong correlation between deforestation and migration in Indonesia. Similar conclusions were drawn from another longitudinal case study in Sulawesi, which concludes that a 1 per cent increase in population due to in-migration leads to a 0.93 per cent increase in forest encroachment for agricultural purposes (Maertens et al. 2002).

In comparison, others who have looked more carefully at the relationship between in-migration and forest change in the Indonesian context point out that correlations do not necessarily imply causation. Even where there is evidence that in-migration has coincided with a corresponding rise in deforestation and forest degradation, the role of a wide range of mediating factors is more important than migration per se. Examples include factors that drive people to migrate to forest frontiers (such as commodity booms, infrastructure projects, government policies) and customary/local institutions that are in place to govern forests (see Thung and Juniwaty 2018 for an extensive review of this literature). Abe's (2006) research on land-use practices among migrant communities in Sumatra's peat swamp forests found that migrant communities for generations have prioritised short-term cultivation of coconut without much regard for long-term sustainability. This is because migrants remain frontier communities, or strangers, because of the difficult biophysical environment of the forest frontier, the cultural and social features of migrants and of receiving communities, and the wider social-economic-political conditions under which migrants operate. For Abe (2006) the wider policy environment is a key determining factor - government policies incentivise migrants to move spontaneously to peat swamp forests but do not address their needs for education or healthcare that would enable them to settle and cultivate over a longer time. Eghenter's (2006) ethnography of new movements of people into the interior of Borneo for large-scale exploitation of particular forest products (gaharu, or aloeswood) also serves as an illustration of the interplay between local institutions and new migration trends in determining environmental outcomes. Eghenter found that the growing movement of outsiders and return migrants in search of quick and lucrative returns from gaharu stretched the ability of the Apo Kayan's customary institutions to physically monitor the arrival of more collectors, and jeopardised internal abilities to develop equitable solutions in the management of gaharu and other forest resources.

Similar studies focusing on effects of other types of migration - out-migration, circular migration and multi-local livelihoods - point to potential synergies and trade-offs between migration and forest outcomes and the role of interacting factors in mediating the relationship between the two (Hecht et al. 2014). Robson and Berkes (2011) found that rural out-migration in Oaxaca, 
Mexico, had contributed to extensive forest resurgence, but also a gradual loss of the forest-agriculture mosaic, resulting in a decline in biodiversity. In this instance, forest resurgence did not automatically translate into biodiversity gain. Parry et al.'s (2010) study in the state of Amazonas in Brazil found that the effect of depopulation of remote areas improved forest cover, but this was largely offset by new threats from logging, gold mining and resource extraction. Padoch et al. (2008) showed that in Amazonia most rural communities have established homes in urban centres, and the movement between rural and urban areas is frequent and commonplace. These households maintain their consumption patterns of forest products even when they move to cities, and they continue to play a role in rural forest-use decisions. In this sense, just as the definition of households is getting fuzzy as they stretch between rural and urban areas, so are patterns of land- and forest-use change.

A subset of literature on the links between remittances (financial and social) and forests mirrors the findings outlined above in the wider scholarship on migration and forests. While some attribute remittances to positive change in forests, others argue that remittances in fact contribute to deforestation and/ or forest degradation (Hecht et al. 2014). In Latin America, migration from rural areas and receipt of remittances has led, in some cases, to an increase in cash incomes and agricultural retraction that has produced forest resurgence. In comparison, Montefrio et al.'s (2014) research among Filipino oil palm workers in Malaysia found that the flow of ideas on land-use decisions from migrants to their family members back in the Philippines influenced farmers' decisions to engage with the oil palm industry in the migrants' home countries. This resulted in a switch from smallholder agricultural practices to largescale, monocultural plantations. Still others, such as Gray and Bilsborrow (2014), point out that remittances and out-migration had mixed, countervailing and weak effects on agricultural and forestry activities.

From an environmental justice perspective, however, even the more careful and nuanced studies do not provide much insights on implications of migration and remittances for distributive, representative and recognition justice. One recent exception is Peluso and Purwanto's (2018) research in Java, Indonesia, which explored the effects of remittances sent by poor and landless women (who were previously presiding illegally in government monopolised forestlands in Java) on state-society power dynamics in forest governance. The study finds that an increasing number of these women are migrating to Hong Kong and other prosperous Asian cities to work as maids and domestic labourers; they send remittances back to their husbands, who remain as formal forest labourers. The remittances pay for everyday household expenses and are eventually invested in agrarian resources that generate income. This has led to an unprecedented increase in investment in 
cows, with a subsequent surge in planting of elephant grass as fodder for the cows in light gaps in the forest understory. Slowly and unintentionally, these women are redressing historical injustices in access to forest resources by making inroads into the control of state monopolised forestlands.

Meanwhile, research on the effects of male out-migration on those left behind in forested landscapes in Nepal is less optimistic and more ambiguous. There are comparatively more studies emanating from Nepal because of the recent surge in large-scale male out-migration for employment purposes in Malaysia and the Gulf countries since the early 2000s (Shrestha 2017), Nepal's reputation as a global leader in innovative participatory environmental governance (Baynes et al. 2015, Fox 2018) and well-established movements for greater social, economic and political justice following the Maoist movement and ensuing civil conflict in the country (Bennett et al. 2013, Sijapati Basnett 2011).

In Nepal, scholars have inquired whether and to what extent male outmigration contributes to environmental justice for marginalised women who are left behind. While some point out that women and marginalised social groups are now able to exercise unprecedented voice and influence in community-wide decision-making processes related to forests (Adhikari and Hobley 2011), others find that such voice is largely offset by a surge in paid and unpaid work burdens that these social groups must now assume. Others rightly recognise that the effects of migration on distributive and representative justice for individuals and social groups are influenced by pre-existing gender and social relations (Sijapati Basnett 2011), a generational divide between migrants and the elderly male population that is left behind (Lama et al. 2017), and the structure and composition of the household (Giri and Darnhofer 2010).

Likewise, in a noteworthy study, Sunam and McCarthy (2015) find that while migration has the potential to lift households and families out of poverty, its effects on distributive justice are mediated by modes of incorporation into migration processes. Those who are better off, with greater social networks, are able to access lucrative migration opportunities, whereas others take up highly risky jobs with limited prospects for upward mobility. Poor and marginalised households incur significant debt in order to pay for migration. Agriculture and forest-based livelihoods subsidise the direct and indirect costs of migration for them. There is limited evidence that migrants invest any surplus income on agriculture and forestry or diversify their livelihoods in a way that lowers their growing dependence on remittance. In this context, the prospects of poor and marginalised migrant workers and their families are limited and highly contingent on the vagaries of the highly unequal market for migrant labour (Fox 2018, Sijapati Basnett and Manandhar 2018). 
Other scholars also point out that not all remittances are invested back into forests or into maintaining or enhancing agrarian capital. This is because of 'opportunity costs of other potential applications of funds and diverse interests of households' (Hecht et al. 2015: 16). For instance, in peri-urban landscapes, significant agricultural and forest retraction has occurred, and migrant investment in real estate and housing speculation is widespread. These landscapes of immigration have been documented in Central America and Mexico (Kandel and Cuellar 2012), in the Andes (Bebbington and Batterbury 2001, Rudel 2006) and in Nepal (Sunam and McCarthy 2015). The effects have not only been a reduction in forest cover and/or decline in incentives to manage commonly held forests, but also heightened environmental injustices. Sunam and McCarthy (2015), for instance, point to aggravated inequalities in access to private and public lands, with potential consequences for food security and nutrition for poor and marginalised social groups.

\subsection{Summary and Concluding Remarks}

This chapter has discussed the potential effects of addressing SDG 10 on forest outcomes from an environmental justice perspective, focusing on two major clusters of issues in SDG 10: inequalities within countries, and migration and remittances. We have defined environmental justice as constituting three notions of justice: distribution, representation and recognition. While distribution notions of justice emerge from socio-economic injustice, recognition relates to symbolic and/or cultural injustice. Representation justice is concerned with parity of participation in institutionalised values and norms, deliberation about rules in distribution and social interactions more broadly. All three notions of justice are intertwined, and yet one is not a precondition for another. Authoritative definitions of environmental justice may clash with and, therefore, have trade-offs with poor and marginalised local peoples' visions of what is just.

We find considerable overlaps among the three notions of justice and SDG 10 targets pertaining to inequalities within countries. However, target aspirations are not fully translated into the corresponding indicators, limiting SDG 10's contribution to environmental justice. Likewise, SDG 10 remains disconnected from SDGs pertaining to environmental sustainability, even when these have bearing on the achievement of SDG 10 and on the promotion of environmental justice.

One of the major gaps within SDG 10 is that trade is not explicitly mentioned, despite mounting concerns about the incompatibility between global systems of trade and goals of equality. A rise in global prices for forest products is often accompanied by unsustainable resource extraction alongside 
consolidation of power and wealth by a few. Rules governing global trade of forest products are increasingly influenced by international and supranational actors, thereby bypassing the state. Such rules are rooted in hegemonic notions of good governance for the 'global good', which are often at odds with the interests of local communities. Alternatively, complying with such rules is only possible for those who can afford to navigate increasingly complicated and costly systems. The consequence has been that smaller actors are being pushed out while normative systems of accountability between the state and marginalised citizens are being disrupted. Such inequalities in the global trading regime have given rise to unprecedented movements for environmental justice. However, current efforts to address these calls remain preoccupied by the need to compensate forest-dependent communities for loss and/or incentivise their action (distributive). Such terms and ideas foreclose the application of representative and recognition notions of justice for poor and marginalised people in forested landscapes.

Therefore, by omitting trade, SDG 10 excludes a major source of inequality within and between countries. It also misses options for redressing historical injustices levelled against poor marginalised social groups and supporting environmental justice movements that truly represent them.

\subsubsection{Targets and Indicators Related to Inequalities within Countries}

The literature on forestry, and on common pool resources more broadly, includes a vast and growing body of scholarship examining the linkages between inequalities and forest outcomes, though epistemological and normative commitments within this scholarship vary considerably. While some argue that there is a clear trade-off or synergy between levels of inequalities and forest outcomes, others view a U-shaped relationship between these two variables. Still others point out that pre-existing levels of inequalities can diminish as long as local people have autonomy over formation of rules to govern their resources and that the institutional arrangements established reflect and/or are adaptable to local conditions. Meanwhile, critical scholarship in the field of environmental justice and political ecology, among others, begins with a recognition that power relations, and thus inequalities, are embedded in formal or bureaucratic institutions as well as informal or socially embedded institutions that govern common property resources. Institutional arrangements do not merely affect nor are they merely affected by inequalities; rather, inequalities are at the very heart of institutional building and change. Deeply rooted relations of caste, class, gender and/or ethnicity (recognition justice), as well as those linked to political participation (representative 
justice) and access to and distribution of resources (distributive justice), are thus reproduced and reinforced in forest-governance institutions.

If SDG 10 successfully reduces broad-based structural inequalities, it is likely to have positive spill-over effects for furthering distributive, representative and recognition justice for forest-dependent populations. However, whether, to what extent and how this will happen remains unclear. Addressing the rising divide between the rich and the poor would require a broad-based political and social agenda, which encompasses reforms in health and education, land tenure, tax and transfer systems, and jobs, to name just a few (see Picketty and Goldhammer 2014, World Bank 2016), while transforming statesociety-market relations (see Hall et al. 2011). All these reforms are in fact covered across the SDG framework, but despite pledges to integrate actions across goals (UN General Assembly 2015), each goal operates in silo. And even within SDG 10, there is a disconnect between the aspirations behind the targets and the choice of corresponding indicators to measure progress against their achievement. Such disjunctions within SDG 10 and between SDG 10 and other SDGs limit the extent to which SDG 10 will amount to transformative changes within and between countries.

\subsubsection{Targets and Indicators Related to Migration and Remittances}

Forestry literature either largely ignores migration and remittances or narrowly frames them as a problem or solution for forests. Even the more nuanced and careful analyses offer limited insights from an environmental justice perspective. The small body of studies that do address these gaps, however, point to an array of mediating variables, such as intra-household dynamics, modes of incorporation into migration, opportunity costs of remittance investment, etc.

In such a context, addressing the migration- and remittance-related targets and indicators in SDG 10 may contribute to greater focus on these issues in the forestry scholarship too. But for SDG 10 to contribute meaningfully towards promoting environmental justice for marginalised individuals and social groups in forested landscapes, policies aimed at 'managing migration' (as outlined in SDG 10) need to consider measures to redress pre-existing injustices in gender and generational lines, offer increased opportunities for poor and socially marginalised groups to migrate and invest their remittances productively, and safeguard access rights of those who are left behind, among other considerations. However, it is unclear whether Target 10.7's focus on planned and well-managed migration policies reflects developmentalist views or narrow nationalist ones. There is a growing consensus among migration 
and development scholars that 'migration alone cannot independently set in motion broader processes of human and economic development' (de Haas 2012: 14). This literature (see de Haan and Roglay 2002, de Haas 2012, Rigg 2006) implies that migration can produce and exacerbate distributive, representative and recognition notions of justice in developing countries between those who are able to migrate and those who cannot afford to; those who migrate to further enhance their livelihood portfolio versus those for whom migration is low return and survivalist (Razavi 2009); and between failed and successful migrants (Sunam and McCarthy 2015). Critics such as Nijenhuis and Leung (2017: 11) caution that such emphasis on managed migration is a reflection of the growing anxiety in Europe and America about the migration 'crisis' and the inflow of refugees in developed countries, rather than a concern for reducing inequalities and promoting justice within migrantsending developing countries and between migrant-receiving (developed) and migrant-sending countries. In this regard, whether or not addressing the migration-related targets and indicators will amount to significant reduction in environmental injustices would depend on what informs the framing of SDG 10: concerns for making migration work for development, or narrow nationalist fears of looming migrant crisis.

\section{References}

Abe, K. 2006. We come to grow coconuts, but not to stay: Temporary migrations into the peat swamp forests of Sumatra. In de Jong, W., Ken-ichi, A. and Tuck-Po, L. (eds.) The social ecology of tropical forests: Migration, populations and frontiers. Melbourne, Australia: Trans Pacific Press, pp. 247-61.

Adhikari, B. and Lovett, J. C. 2006. Transaction costs and community-based natural resource management in Nepal. Journal of Environmental Management 78(1):5-15.

Adhikari, J. and Hobley, M. 2011. Everyone is leaving - Who will sow our fields? The effects of migration from Khotang District to the Gulf and Malaysia. Kathmandu: Nepal Institute of Development Studies (NIDS).

Agarwal, B. 2001. Participatory exclusions, community forestry and gender: An analysis for South Asia and a conceptual framework. World Development 29(10):1623-48.

Agarwal, B. 2002. The hidden side of group behaviour: A gender analysis of community forestry groups. In Heyer, J., Stewart, F. and Thorp, E. (eds.) Group behaviour and development: Is the market destroying cooperation? Oxford: Oxford University Press, pp. 185-208.

Agarwal, B. 2010. Gender and green governance: The political economy of women's presence within and beyond community forestry. Oxford: Oxford University Press.

Agarwal, B. 2016. Environmental change and collective action. Vol. 3 of Gender challenges. Oxford: Oxford University Press. 
Agrawal, A. and Benson, C. S. 2011. Common property theory and resource governance institutions: Strengthening explanations of multiple outcomes. Environmental Conservation 38(2):199-210.

Agrawal, A. and Gibson, C. G. 1999 enchantment and disenchantment: The role of community in natural resource conservation. World Development 27(4):629-49.

Agrawal, A. and Ostrom, E. 2001. Collective action, property rights and decentralisation in resource use in India and Nepal. Politics \& Society 29(4):485-514.

Agyeman, J. 2005. Sustainable communities and the challenge of environmental justice. New York: New York University Press.

Andersson, K. and Agrawal, A. 2011. Inequalities, institutions and forest commons. Global Environmental Change 21:866-75.

Appave, G. and Sinha, N. (eds.) 2017. Migration in the 2030 Agenda. Geneva: International Organization for Migration. Available at: https://publications.iom.int/system/files/pdf/ migration_in_the_2030_agenda.pdf (Accessed 8 May 2018).

Astuti, R. and McGregor, A. 2016. Indigenous land claims or green grabs? Inclusions and exclusions within forest carbon politics in Indonesia. The Journal of Peasant Studies 44(2):445-66.

Bair, J. 2005. Global capitalism and commodity chains: Looking back, going forward. Competition \& Change 9:153-80.

Baker, J. M. 1998. The effect of community structure on social forestry outcomes: Insights from Chota Nagpur, India. Mountain Research and Development 18:51-62.

Baland, J. M. and Platteau, J. P. 1999. The ambiguous impact of inequality on local resource management. World Development 27(5):773-88.

Bandiaky, S. 2008. Gender inequality in Malidino Biodiversity Community-based Reserve, Senegal: Political parties and the 'village approach'. Conservation and Society 6(1):62-73.

Bartley, T. 2007. How foundations shape social movements: The construction of an organizational field and the rise of forest certification. Social Problems 54:229-55.

Baynes, J., Herbohn, J., Smith, C., Fisher, R. and Bray, D. 2015. Key factors which influence the success of community forestry in development countries. Global Environmental Change 35:226-38.

Bebbington, A. J. and Batterbury, S. P. J. 2001. Transnational livelihoods and landscapes: Political ecologies of globalization. Cultural Geographies 8(4):369-80.

Beck, T. and Nesmith, C. 2001. Building on poor people's capacities: The case of common property resources in India and West Africa. World Development 29(1):119-33.

Belcher, B. and Schreckenberg, K. 2007. Commercialisation of non-timber forest products: A reality check. Development Policy Review 25(3):355-77.

Bennett, L., Sijapati, B. and Thapa, D. 2013. Gender and social exclusion in Nepal: Update. Kathmandu, Nepal: Himal Books.

Bernstein, S. and Cashore, B. 2007. Can non-state global governance be legitimate? An analytical framework. Regulation \& Governance 1:347-71. 
Black, R., Adger, W. N., Arnell, N. W. et al. 2011. The effect of environmental change on human migration. Global Environmental Change 21:S3-S11.

Brockington, D., Duffy, R. and Igoe, J. 2008. Nature unbound: Conservation, capitalism and the future of protected areas. London: Earthscan/James \& James.

Budhathoki, P. 2004. Linking communities with conservation in developing countries: Buffer zone management initiatives in Nepal. Oryx 38:334-41.

Bullard, R. D. 2005. The quest for environmental justice: Human rights and the politics of pollution. Berkeley: University of California Press.

Byrne, S., Nightingale, A. J. and Korf, B. 2016. Making territory: War, post-war and the entangled scales of contested forest governance in mid-western Nepal. Development and Change 47(6):1269-93.

Carr, D. 2009a. Rural migration: The driving force behind tropical deforestation on the settlement frontier. Progress in Human Geography 33(3):355-78.

Carr, D. 2009b. Population and deforestation: Why rural migration matters. Progress in Human Geography 33(3):355-78.

Carr, E. R. 2005. Placing the environment in migration: Environment, economy and power in Ghana's central region. Environment and Planning A 37:925-46.

Cashore, B. 2002. Legitimacy and the privatization of environmental governance: How nonstate market-driven (NSMD) governance systems gain rule-making authority. Governance 15(4):503-29. Available at: https://onlinelibrary.wiley.com/doi/abs/10.1111/14680491.00199 (Accessed 27 July 2019)

Cashore, B., Auld, G., Bernstein, S. and McDermott C. 2007. Can non-state governance 'ratchet up' global environmental standards? Lessons from the forest sector. Review of European Comparative \& International Environmental Law 16(2):158-72.

Cerutti, P. O. and Tacconi, L. 2008. Forests, illegality, and livelihoods: The case of Cameroon. Society \& Natural Resources 21(9):845-53.

Chatterton, B. and Chatterton, L. 2001. The Australian water market experiment. Water International 26(1):62-7.

Chaudhary, S., McGregor, A., Houston, D. and Chettri, N. 2018. Environmental justice and ecosystem services: A disaggregated analysis of community access to forest benefits. Ecosystem Services 29:99-115.

Chomba, S., Kariuki, J., Lund, J. F. and Sinclair, F. 2015. Roots of inequity: How the implementation of REDD+ reinforces past injustices. Land Use Policy 50:202-13.

Cleaver, F. 2002. Reinventing institutions: Bricolage and the social embeddedness of natural resource management. European Journal of Development Research 14(2):11-30.

Cole, L. and Foster, S. 2001. From the ground up: Environmental racism and the rise of the environmental justice movement. New York: New York University Press.

Coomes, O. T., Takasaki, Y. and Rhemtulla, J. M. 2016. Forests as landscapes of social inequality: Tropical forest cover and land distribution among shifting cultivators. Ecology and Society 21(3):20. 
Corbera, E., Kosoy, N. and Martinez Tuna, M. 2007. Equity implications of marketing ecosystem services in protected areas and rural communities: Case studies from Meso-America. Global Environmental Change 17:365-80.

Darmawan, R., Klasen, S. and Nuryartono, N. 2016. Migration and deforestation in Indonesia. EFForTS Discussion Paper Series No. 19. Goettingen: University of Goettingen.

Dayton-Johnson, J. and Bardhan, P. 2002. Inequality and conservation on the local commons: A theoretical exercise. The Economic Journal 112(481):577-602.

De Haan, A. and Rogaly, B. 2002. Introduction: Migrant workers and their role in rural change. Journal of Development Studies 38:1-14.

De Haas, H. 2012. The migration and development pendulum: A critical view on research and policy. International Migration 50(3):8-25.

Djoudi, H. and Brockhaus, M. 2011. Is adaptation to climate change gender neutral? Lessons from communities dependent on livestock and forests in northern Mali. International Forestry Review 13:123-35.

Dove, M. 1994. Marketing the rainforest: 'Green' panacea or red herring? Asia Pacific Issues: Analysis from the East-West Center 13.

Eghenter, C. 2006. Movements, social entitlements and economic fortunes in the forests of the interior of Borneo. In de Jong, W., Tuck-Po, L. and Ken-Ichi, A. (eds.) The social ecology of tropical forests: Migration, population and frontiers. Kyoto: Kyoto University Press, pp. 228-46.

Elias, M. and Arora-Jonsson, S. 2017. Negotiating across difference: Gendered exclusions and cooperation in the shea value chain. Environment Planning D: Society and Space 35(1):107-25.

Elias, M. and Carney, J. 2007. African shea butter: A feminized subsidy from nature. Africa 77(1):37-62.

Espach, R. and Ralph, E. 2006. When is sustainable forestry sustainable? The Forest Stewardship Council in Argentina and Brazil. Global Environmental Politics 6:55-84.

Forsyth, T. 2014. Climate justice is not just ice. Geoforum 54:230-2.

Forsyth, T. J. and Sikor, T. 2013. Forests, development and the globalisation of justice. Geographical Journal 179:114-21.

Fox, J. 2018. Community forestry, labor migration and agrarian change in a Nepali village: 1980 to 2010. Journal of Peasant Studies 45(3):610-29.

Fraser, N. 1995. From redistribution to recognition? Dilemmas of justice in a 'post-socialist' age. New Left Review I/212, July-August.

Fraser, N. 2009. Scales of justice: Reimagining political space in a globalizing world. New York: Columbia University Press.

Giri, K. and Darnhofer, I. 2010. Outmigrating men: A window of opportunity for women's participation in community forestry? Scandinavian Journal of Forest Research 25(9):55-61.

Gray, C. L. and Bilsborrow, R. E. 2014. Consequences of out-migration for land use in rural Ecuador. Land Use Policy 36(1):182-91.

Green, K. E. and Lund, J. F. 2014. The politics of expertise in participatory forestry: A case from Tanzania. Forest Policy and Economics 60:27-34. 
Guneratne, A. 2002. Many tongues, one people: The making of Tharu identity in Nepal. Ithaca: Cornell University Press.

Hajjar, R. 2014. Advancing small-scale forestry under FLEGT and REDD in Ghana. Forest Policy and Economics 58:12-20.

Hall, D., Hirsch, P. and Murray Li, T. 2011. Powers of exclusion: Land dilemmas in Southeast Asia. Honolulu: University of Hawaii Press.

Hardin, R. 1982. Collective action. Baltimore: Johns Hopkins Press.

Harvey, D. 2004. The 'New' Imperialism: Accumulation by Dispossession. Socialist Register 40. Available at: www.socialistregister.com/index.php/srv/article/view/5811 (Accessed 24 February 2019).

Hébert, M. and Rosen, M. G. 2007. Community forestry and the paradoxes of citizenship in Mexico: The cases of Oaxaca and Guerrero. Canadian Journal of Latin American and Caribbean Studies 32:9-44.

Hecht, S. B., Kandel, S. and Morales, A. 2012. Migration, livelihoods and natural resources. San Salvador: IDRC PRISMA.

Hecht, S. B., Morrison, K. D. and Padoch, C. (eds.) 2014. The social lives of forests: Past, present, and future of woodland resurgence. Chicago: University of Chicago Press.

Hecht S., Yang A. L., Sijapati Basnett B., Padoch C. and Peluso N. L. 2015. People in motion, forests in transition: Trends in migration, urbanization and remittances and their effects on tropical forests. CIFOR Occasional Paper 142. Bogor, Indonesia: CIFOR.

Hickel, J. 2017. The Divide: A Brief Guide to Global Inequality and its Solutions. William London: Heinemann.

Hoffer, A. 1979. The caste hierarchy and the state in Nepal: A study of the Mulki Ain in 1854. Innsbruck: Universitätsverlag Wagner (Khumbu Himal: Ergebnisse des Forschungsunternehmens Nepal Himalaya).

Holmes, G. and Cavanagh, C. J. 2016. A review of the social impacts of neoliberal conservation: Formations, inequalities, contestations. Geoforum 75:199-209.

IIED 2016. Five considerations for national evaluation agendas informed by SDGs. Briefing. 2016. Available at: http://pubs.iied.org/17374IIED (Accessed 8 May 2018).

Islam, S. N. 2015. Inequality and environmental sustainability. DESA Working Paper No. 145. New York: United Nations Department of Economic and Social Affairs (DESA).

Jasanoff, S. and Martello, M. L. (eds.) 2004. Earthy Politics: Local and Global in Environmental Governance. Cambridge, MA: MIT Press.

Jodha, N. S. 1985. Population growth and the decline of common property resources in Rajasthan, India. Population and Development Review 11:247-64.

Johnson, C. 2004. Uncommon ground: The 'poverty of history' in common property discourse. Development and Change 35(3):407-34.

Kabeer, N. 2015. Gender equality, the MDGs and the SDGs: Achievements, lessons and concerns. International Growth Center. Available at: www.theigc.org/blog/gender-equality-the-mdgsand-the-sdgs-achievements-lessons-and-concerns/ (Accessed 1 May 2018). 
Kabeer, N. and Santos, R. 2017. Intersecting inequalities and the Sustainable Development Goals: Insights from Brazil. Working Paper 14. International Inequalities Institute, London School of Economics and Political Science. Available at: www.wider.unu.edu/sites/default/files/ Publications/Working-paper/PDF/wp2017-167.pdf (Accessed 15 September 2018).

Kandel, S. and Cuellar, N. 2012. Migration Dynamics, rural Livelihoods and Challenges for Territorial Management: Lessons from El Salvador. In Hecht, S. B., Kandel, S. and Morales, A. (eds.) Migration, Livelihoods and Natural Resources San Salvador. IDRC, pp. 125-146.

Khatun, K., Gross-Camp, N., Corbera, E., Martin, A. and Glory Massao, S. B. 2015. When participatory forest management makes money: Insights from Tanzania on governance, benefit sharing and implications for REDD+. Environment and Planning 47:2097-2112.

Kopnina, H. 2017. Commodification of natural resources and forest ecosystem services: Examining implications for forest protection. Environmental Conservation 44(1):24-33.

Kumar, K. 2014. The sacred mountain: Confronting global capital at Niyamgiri. Geoforum 54:196-206.

Lama, A. S., Kharel, S. and Ghale, T. 2017. When the men are away: Migration and women's participation in Nepal's Community Forestry. Mountain Research Development 37(3):263-70.

Larson, A. M., Barry, D., Dahal, G. R. and Colfer, C. J. P. (eds.) 2010. Forests for people: Community rights and forest tenure reform. London: Earthscan.

Leach, M., Mearns, R. and Scoones, I. 1999. Environmental entitlements: Dynamics and institutions in community-based natural resource management. World Development 27(2):225-47.

Levine, N. E. 1987. Caste, state and ethnic boundaries in Nepal. Journal of Asian Studies 46(1):81-8.

Li, T. M. 1996. Images of community: Discourse and strategy in property relations. Development and Change 27(3):501-27.

Li, T. M. 2017. Rendering land investible: Five notes on time. Geoforum 82:276-8.

Lund, C. 2016. Rule and rupture: State formation through the production of property and citizenship. Development and Change 47(6):1199-228.

Maertens, M., Zeller, M. and Birner, R. 2002. Explaining agricultural land use in villages surrounding the Lore Lindu National Park in Central Sulawesi, Indonesia. STORMA Discussion Paper Series No. 4. Bogor, Indonesia: Stability of Rain Forest Margins (STORMA).

Marcone, M. F. 2005. Characterization of the edible bird's nest the 'Caviar of the East'. Food Research International 38:1125-34.

Martin, A. (ed.) 2013. Global environmental in/justice, in practice: Introduction. Geographical Journal 179(2):98-104.

Martin, A. 2017. Just conservation: Biodiversity, wellbeing and sustainability. London: Routledge.

Marx, K. 1867. Capital: A Contribution to the Critique of Political Economy, (ed.) Frederick Engels. Moscow: Progress Publishers.

Maryudi, A. and Myers, R. 2018. Renting legality: How FLEGT is reinforcing power relations in Indonesian furniture production networks. Geoforum 97:46-53. 
Maryudi, A., Nawir, A. A., Permadi, D. B. et al. 2015. Complex regulatory frameworks governing private smallholder tree plantations in Gunungkidul District, Indonesia. Foreign Policy and Economics 59:1-6.

Mearns, R. 1996. Environmental entitlements: Pastoral natural resource management in Mongolia. Cahiers des Sciences Humaines 32(1):105-31.

Metha, L., Allouche, J., Nicol, A. and Walnycki, A. 2014. Global environmental justice and the right to water: The case of peri-urban Cochabamba and Delhi. Geoforum 54:158-66.

Milanovic, B. 2012. Global inequality: From class to location, from proletarians to migrants. Global Policy 3(2):125-34.

Molinas, J. R. 1998. The impact of inequality, gender, external assistance and social capital on local-level cooperation. World Development 26:413-31.

Montefrio, M. J. F., Ortiga, Y. Y. and Josol, M. 2014. Inducing development: Social remittances and the expansion of oil palm. International Migration Review 48(1):216-42.

Moore, D. S. 1993. Contesting terrain in Zimbabwe's Eastern Highlands: Political ecology, ethnography, and peasant resource struggles. Economic Geography 69(4):380-401.

Moore, J. W. 2010. The End of the Road? Agricultural Revolutions in the Capitalist Worldecology, 1450-2010. Journal of Agrarian Change 10(3):389-413.

Mosse, D. 1997. The symbolic making of a common property resource: History, ecology and locality in a tank-irrigated landscape in South India. Development and Change 28(3):467-504.

Mukhopadhyay, L. 2004. Inequality, differential technology for resource extraction and voluntary collective action in commons. Ecological Economics 49(2):215-30.

Mulvaney, D. 2014. Are green jobs just jobs? Cadmium narratives in the life cycle of photovoltaics. Geoforum 54:178-86.

Myers, R. 2015. Access in a Global Rattan Production Network. Norwich: University of East Anglia.

Myers, R., Intarini, D., Sirait, M. T. and Maryudi, A. 2017. Claiming the forest: Inclusions and exclusions under Indonesia's 'new' forest policies on customary forests. Land Use Policy 66:205-13.

Myers, R., McDermott, C. L., Rutt, R. et al. Forthcoming. Imposing legality: The hegemonic notions of forest governance in the EU Forest Law Enforcement, Governance and Trade (FLEGT).

Myers, R. and Muhajir, M. 2015. Searching for justice: rights vs 'benefits' in Bukit Baka Bukit Raya National Park, Indonesia. Conservation \& Society 13:370-81.

Neupane, H. 2003. Contested Impact of community forestry on equity: Some evidences from Nepal. Journal of Forest and Livelihoods 2(2):55-62.

Newell, P. 2005. Race, class and the global politics of environmental inequality. Global Environmental Politics 5(3):70-93.

Newell, P. 2006. Environmental justice movements: Taking stock, moving forward. Environmental Politics 15(4):656-60.

Newell, P. 2007. Trade and environmental justice in Latin America. New Political Economy 12(2):237-59.

Nijenhuis, G. and Leung, M. 2017. Rethinking migration in the 2030 Agenda: Towards a deterritorialized conceptualization of development. Forum for Development Studies 44(1):51-68. 
Okereke, C. and Dooley, K. 2010. Principles of justice in proposals and policy approaches to avoided deforestation: Towards a post-Kyoto climate agreement. Global Environmental Change 20:82-95.

Olson, M. 1965. The logic of collective action: Public goods and the theory of groups. Cambridge, MA: Harvard University Press.

Padoch, C., Brondizio, E., Costa, S., Pinedo-Vasquez, M., Sears, R. R. and Siqueira, A. 2008. Urban forest and rural cities: Multi-sited households, consumption patterns, and forest resources in Amazonia. Ecology and Society 13(2):2.

Parry, L., Day, B., Amaral, S. and Peres, C. A. 2010. Drivers of rural exodus from Amazonian headwaters. Population and Environment 32:137-76.

Peluso, N. L. 1994. Rich forests, poor people: Resource control and resistance in Java. Berkeley: University of California Press.

Peluso, N. L. and Lund, C. 2011. New frontiers of land control: Introduction. Journal of Peasant Studies 38(4):667-81.

Peluso, N. L. and Purwanto, A. B. 2018. The remittance forest: Turning mobile labour into agrarian capital. Singapore Journal of Tropical Geography 39(1):6-36.

Piketty, T. and Goldhammer, A. 2014. Capital in the twenty-first century. Cambridge, MA: The Belknap Press of Harvard University Press.

Poteete, A. R. and Ostrom, E. 2004. Heterogeneity, group size and collective action: The role of institutions in forest management. Development and Change 35(3):435-61.

Potter, L. 2012. New transmigration 'paradigm' in Indonesia: Examples from Kalimantan. Asia Pacific Viewpoint 53(3):272-87.

Quiggin, J. 1982. A theory of anticipated utility. Journal of Economic Behavior \& Organization 3(4):323-43.

Rangan, H. and Kull, C. A. 2009. What makes ecology 'political'? Rethinking 'scale' in political ecology. Progress in Human Geography 33(1):28-45.

Ratha, D. 2005. Remittances: A lifeline for development. Finance and Development 42(4).

Rawls, J. 1999. A theory of justice, rev. ed. Cambridge, MA: Harvard University Press.

Razavi, S. 2009. Engendering the political economy of agrarian change. Journal of Peasant Studies 36(1):197-226.

Ribot, J. C. and Peluso, N. L. 2003. A theory of access. Rural Sociology 68(2):153-81.

Rigg, J. 2006. Land, farming, livelihoods, and poverty: Rethinking the links in the rural South. World Development 34(1):180-202.

Robbins, P. 2004. Political ecology: A critical introduction. Oxford: John Wiley \& Sons Ltd.

Robson, J. P. and Berkes, F. 2011. Exploring some of the myths of land use change: Can rural to urban migration drive declines in biodiversity? Global Environmental Change 21(3):844-54.

Roser, M. 2018. Global economic inequality. Available at: https://ourworldindata.org/globaleconomic-inequality (Accessed 15 November 2018).

Rudel, T. K. 2006. After the labor migrants leave: The search for sustainable development in a sending region of the Ecuadorian Amazon. World Development 34(5):838-51.

Ruiz-Pérez, M., Belcher, B., Achdiawan, R. et al. 2004. Markets drive the specialization strategies of forest peoples. Ecology and Society 9(2):4. 
Sandler, T. 2015. Collective action: Fifty years later. Public Choice 164:195-216

Schepers, D. H. 2009. Challenges to legitimacy at the Forest Stewardship Council. Journal of Business Ethics 92:279-90.

Schlosberg, D. 2004. Reconceiving environmental justice: Global movements and political theories. Environmental Politics 13(3):517-40.

Schlosberg, D. 2007. Defining environmental justice: Theories, movements, and nature. Oxford: Oxford University Press.

Schlosberg, D. 2013. Theorising environmental justice: The expanding sphere of a discourse. Environmental Politics 22:37-55.

Schoenberger, L., Hall, D. and Vandergeest, P. 2017. What happened when the land grab came to Southeast Asia? Journal of Peasant Studies 44(4):697-725.

Schroeder, H. and McDermott, C. 2014. Beyond carbon: Enabling justice and equity in REDD+ across levels of governance. Ecology and Society 19:31.

Scoones, I. 1999. New ecology and the social sciences: What prospects for fruitful engagement? Annual Review of Anthropology 28:479-507.

Scott, J. C. 1999. Seeing like a state: How certain schemes to improve the human condition have failed. New Haven: Yale University Press.

Seabright, P. 1993. Managing local commons: Theoretical issues in incentive design. Journal of Economic Perspectives 7(4):113-34.

Secrett. C. 1986. The environmental impact of transmigration. The Ecologist 16(2/3):77-88.

Sen, A. 1981. Poverty and famines. Oxford: Oxford University Press.

Sen, A. 2009. The idea of justice. Cambridge, MA: Harvard University Press.

Shrestha, M. 2017. The Impact of Large-Scale Migration on Poverty, Expenditures, and Labor Market Outcomes in Nepal. Policy Research Working Paper No. 8232. Washington, DC: World Bank.

Sijapati Basnett, B. 2011. Linkages between gender, migration and forest governance: Rethinking community forestry policies in Nepal. European Bulletin of Himalayan Research 38:9-34.

Sijapati Basnett, B. 2018. UN Women's evaluation of gender in the SDGs: What's the role for the CGIAR? CIFOR Infobrief No.229. Bogor, Indonesia: CIFOR.

Sijapati Basnett, B. and Manandhar, S. 2018. Effects of large-scale male out-migration on the left behind populations and land: Insights from Nepal. Paper presented the CGIAR Annual Gender Conference and Capacity Development Workshop, Addis Ababa, Ethiopia, September 26, 2018.

Sikor, T. 2010. Forest justice: Towards a new agenda for research and practice? Journal of Integrative Environmental Sciences 7(4):245-50.

Sikor, T. (ed.) 2013. The justices and injustices of ecosystem services. London: Earthscan.

Sikor, T. and Lund, C. 2010. The politics of possession: Property, authority, and access to natural resources. Hoboken: Wiley-Blackwell,

Sikor, T. and Newell, P. 2014. Globalizing environmental justice? Geoforum 54:151-7.

Sikor, T. and Stahl, J. 2011. Introduction: The rights-based agenda in international forestry. In Sikor, T. and Stahl, J. (eds.) Forests and people. London: Earthscan, pp. 1-13. 
Siscawati, M., Banjade, M. R., Liswanti, N. et al. 2017. Overview of forest tenure reforms in Indonesia. Working Paper No. 223. Bogor, Indonesia: CIFOR.

Smith, L. 2004. The murky waters of the second wave of neoliberalism: Corporatization as a service delivery model in Cape Town. Geoforum 35(3):375-93.

Soehartono, T. and Newton, A. C. 2002. The gaharu trade in Indonesia: Is it sustainable? Economic Botany 56:271-84.

Stuart, E. and Woodroffe, J. 2016. Leaving no-one behind: Can the Sustainable Development Goals succeed where the Millennium Development Goals lacked? Gender \& Development 24(1):69-81.

Suiseeya, K. R. M. 2017. Contesting Justice in Global Forest Governance: The Premises and Pitfalls of REDDD+. Conservation and Society 15(2):189-200.

Sunam, R. K. and McCarthy, J. F. 2010. Advancing equity in community forestry: Recognition of the poor matters. International Forestry Review 12:370-82

Sunam, R. K. and McCarthy, J. F. 2015. Reconsidering the links between poverty, international labor migration, and agrarian change: Critical insights from Nepal. Journal of Peasant Studies 43(1):39-63.

Taylor, P. 2000. Producing more with less: Community forestry in Durango, Mexico, in an era of trade liberalisation. Rural Sociology 65:253-74.

Thung, P. H. and Juniwaty, K. S. 2018. Missing links in the forest-migration nexus. CIFOR Occasional Paper no. 186. Bogor, Indonesia: CIFOR.

Thurow, L. C. 1975. Generating Inequality: Mechanisms of distribution in the US Economy. London: Macmillan Press.

Trawick. P. B. 2001. Successfully governing the commons: Principles of social organization in an Andean irrigation system. Human Ecology 29(1):1-25

UN DESA (United Nations Department of Economic and Social Affairs) 2015. Concepts of Inequality. Development Issues No.1. Department of Economic and Social Affairs. Available at: www.un.org/en/development/desa/policy/wess/wess_dev_issues/dsp_policy_01.pdf (Accessed 13 January 2019).

UNDP (United Nations Development Programme) 2013. Humanity divided: Confronting inequality in developing countries. New York: UNDP. Available at: www.undp.org/content/undp/ en/home/librarypage/poverty-reduction/humanity-divided-confronting-inequality-indeveloping-countries.html (Accessed 27 July 2019).

United Nations General Assembly 2015. Transforming our world: The 2030 Agenda for Sustainable Development. Resolution adopted by the General Assembly on 25 September 2015, Available at: www.un.org/ga/search/view_doc.asp?symbol=A/RES/70/1\&Lang=E (Accessed 15 November 2018).

UN Women 2018. Turning promises into action: Gender equality in the 2030 Agenda for Sustainable Development. New York: UN Women.

Varughese, G. and Ostrom, E. 2001. The contested role of heterogeneity in collective action: Some evidence from community forestry in Nepal. World Development 29(5):747-65. 
Walker, G. 2009. Globalising environmental justice: The geography and politics of frame contextualization and evolution. Global Social Policy 9(3):355-82.

Walker, G. 2012. Environmental justice: Concepts, evidence and politics. London: Routledge.

White, B., Borras Jr., S. M., Hall, R., Scoones, I. and Wolford, W. 2012. The new enclosures. Critical perspectives on corporate land deals. Journal of Peasant Studies 39(3-4):619-47.

Williamson, J. A. 2000. Globalization and Inequality, Past and Present. In Frieden J. A. and Lake, D. A. (eds.) International Political Economy. Boston: Bedford/St. Martin's, pp. 405-16.

Willis, K. 2016. Viewpoint: International development planning and the Sustainable Development Goals (SDGs). International Development Planning Review (IDPR) 38(2):105-11.

Wollenberg, E. K. 2001. Incentives for collecting gaharu (fungal-infected wood of Aquilaria SPP., Thymelaeaceae) in East Kalimantan. Economic Botany 55:444-56.

World Bank 2009. Roots for good forest outcomes: An analytical framework for governance reforms. Washington, DC: World Bank Agriculture and Rural Development Department.

World Bank 2016. Poverty and shared prosperity 2016: Taking on inequality. Washington, DC: World Bank. Available at: www.worldbank.org/en/publication/poverty-and-sharedprosperity (Accessed 15 January 2019).

World Bank 2016. Indonesia's Rising Divide. World Bank, Jakarta. Available at: https:// openknowledge.worldbank.org/handle/10986/24765 (Accessed on 23 February 2019).

Wunder, S., Angelsen, A. and Belcher, B. 2014a. Forests, livelihoods, and conservation: Broadening the empirical base. World Development 64:S1-S11.

Wunder, S., Borner, J., Shively, G. and Wyman, M. 2014b. Safety nets, gap filling and forests: A global comparative perspective. World Development 64:S29-S42.

Zapata-Ríos, O., Vadez, V., Godoy, R. et al. 2014. Income inequality and deforestation: Evidence from a small-scale, pre-industrial society in the Bolivian Amazon. TAPS Working Paper Series, Tsimane' Amazonian Panel Study.

Zimmerer, K. S. and Basset, T. (eds.) 2003. Political ecology: An integrative approach to geography and environment-development studies. New York: Guildford Press. 